\title{
A Reversal in the Historical Role of Tariffs in Economic Growth? The Cases of Brazil and Portugal ${ }^{+}$
}

\author{
- Maria Eugénia Mata*
}

- JOSEPH L. LOVE**

\begin{abstract}
RESUMO
Este artigo discute o papel comparativo do protecionismo sobre o crescimento econômico brasileiro e português no período 1860-1950 no contexto das aproximações teóricas disponíveis da Economia Internacional. Embora o papel das tarifas tenha sido longamente discutido na historiografia dos dois países, este artigo fornece o primeiro exercício que usa a metodologia baseada na aproximação macroeconométrica para sucessões cronológicas de longa duração. Dada a conclusão de Clemens e Williamson de que o enquadramento mundial conta, testamos para os dois países a sua pretensão do tariff reversal paradox. As experiências brasileira e portuguesa confirmam que a proteção esteve correlacionada com o crescimento no período anterior à Primeira Guerra Mundial, e não é provável que comércio mais livre tivesse aumentado o crescimento econômico português, contrariamente à tese estabelecida. A Primeira Guerra Mundial, contudo, foi um momento decisivo para o Brasil. Ao fazer-se este estudo, usaram-se os melhores dados disponíveis, partindo-se ocasionalmente dos usados por Clemens e Williamson. As nossas conclusões prevalecem com dados alternativos.
\end{abstract}

\section{Palavras-Chave}

tarifas, paradoxo tarifas-crescimento, crescimento econômico, proteccionismo, Portugal, Brasil

\begin{abstract}
This paper discusses the comparative role of protectionism on Brazilian and Portuguese economic growth for the period I860-1950 in the context of the available theoretical approaches from international economics. Although the role of tariffs has long been debated in the historiography of both countries, this paper provides the first exercise that uses a methodology based on a macro-econometric approach for long-run time-series. Given Clemens' and Williamson's conclusion that the world environment matters, we test their claim for two countries on the tariff reversal paradox. The Brazilian and the Portuguese experiences confirm that protection was correlated with growth in the period before World War I, and it is unlikely that freer trade would have increased Portuguese growth, contrary to the established thesis. The First World War, however, was a turning point for Brazil. In carrying out this study, we have used the best data available to us, occasionally departing from those used by Clemens and Williamson. Our conclusions hold for alternative data sets.
\end{abstract}

\section{KEYWORDS}

tariffs, tariff-growth paradox, economic growth, protectionism, Portugal, Brazil

\section{Jel Classification}

$\mathrm{FI}, \mathrm{N} / \mathrm{O}, \mathrm{N} / 3, \mathrm{~N} / 4, \mathrm{~N} / 6$

+ This paper was originally prepared for the I4th International Economic History Congress in Helsinki, Finland, in 2006. The two authors thank Jeffrey Williamson for letting us use his and Michael Clemens' data. We also thank Ana Bela Nunes for data on Portuguese literacy rate, Ana Balcão Reis for bibliography, and Luís Catela Nunes, André Castro e Silva, Francesco Franco and participants of the pre-session in Mexico for discussion and econometric advice. Finally, we are especially indebted to Saket Sarraf for his expert statistical services. All errors are our responsibility.

* Universidade Nova de Lisboa, Faculdade de Economia. Contact adress: Faculdade de Economia - Universidade Nova de Lisboa - Campus de Campolide - 1099-032 - Lisboa - Portugal. E-mail: memata@fe.unl.pt.

** University of Illinois, Center for Latin American and Caribbean Studies. E-mail: j-love2@uiuc.edu.

(Recebido em novembro de 2006. Aceito para publicação em outubro de 2007). 


\section{INTRODUCTION}

Protection and free trade have long been debated in economic theory and economic history. However, it is possible to say that the precise relationship between openness or free trade and long run economic growth remains a difficult theoretical issue that is being explored in a variety of ways. ${ }^{1}$ Do open economies grow faster than closed economies?

The answer is one to which economic historians can contribute, because, according to Dinopoulos and Syropoulos (1997) "mainstream economics (...) does not leave any room for policy effects on long-run economic growth". ${ }^{2}$ Moreover, past (classical and neoclassical) economics could not answer this question because it requires a global approach that only general equilibrium and recent developments in game theory can provide. ${ }^{3}$ So, an economic history approach may present empirical findings that will challenge theoretical analysts to provide new solutions.

The literature was based on the Smithian and Ricardian conclusions reinforced by the Hecksher-Ohlin theorem that recommends free trade as the best commercial policy because of its positive effects on growth and welfare of both commercial partners. This doctrine that is focused on improvements in the level of income is based on static frameworks that may limit the interpretation of long-run effects. It was in turn reinforced with the Stopler-Samuelson theorem that pointed to an increase of the remuneration for scarcer mobile productive factors in a freer trade context. Using this theoretical context, economic historians may ask why so many times and in so many countries governments used protectionist policies, if free trade was so favorable to growth and welfare ${ }^{4}$ Of course, one may concede that political lobbying may explain protectionism because of the redistribution effects on revenue that are involved in the so-called specific-factors models. In these schemes, trade liberalization provokes losses in all productive factors associated with the importcompeting sectors against other (immobile) factors. However, it is possible that in many countries trade policy depended much more on the personal preferences and ideas of politicians, because, speaking historically, their constituents rarely had strong preferences about trade policy and even more rarely communicated them to their political representatives. As Bauer and Dexter (1972) conclude trade policy remains an unfathomable issue for the lay public today.

Clemens and Williamson (2002) - CW from now on - use an economic history approach to study the effects of protection on economic growth from 1860 to 1950.

1 For a perspective based on sociological and political views, see Milner (1999).

2 p. 425.

3 Dinopoulos and Syropoulos (1997, p. 426).

4 For a survey on this question see Rodrik (1995). 
They employ a sample of 35 countries using a cross-section analysis for panel data. They conclude that protection favoured growth before the Second World War. Since growth after 1945 or 1950 coincides with openness, World War II was surely a turning point, they say. They remark that "economists have had to look for more late $20^{\text {th }}$ century proof to support the openness-fosters-growth hypothesis" ${ }^{5}$ In fact, the association between openness and growth in the postwar period is no longer undisputed. Rodríguez and Rodrik (2001) raise questions about several papers that try to prove that openness was centrally related to growth after World War II. In fact, according to Rodrik (1999) "today the benefits of openness are oversold routinely in the policy-relevant literature". Also, according to Yanikkava (2003), trade liberalization does not have a simple and straightforward relationship with growth. ${ }^{6}$

CW argue that there is a tariff reversal paradox, because before World War II protection was favorable to, or at least associated with, economic growth. Curiously, thirty years ago Bairoch (1972) had also concluded that European "protectionist countries grew faster in the nineteenth century, not slower, as every economist has found for the late twentieth century". ${ }^{7}$ Bairoch reached this conclusion without considering variables other than growth and tariffs, but Kevin O'Rourke (2000) provides new credibility to Bairoch's thesis by using a macro-econometric analysis with a large array of growth-related variables. CW use a similar methodology for checking the tariff-growth paradox.

This paper examines how the thesis of the tariff reversal paradox applies in two cases, those of Brazil and Portugal, considering the period from the 1860s-1870s to 1945. Both of these countries were included in the CW data set. ${ }^{8}$

\section{CONTEXTUALIZING THE BRAZILIAN AND PORTUGUESE CASES}

CW grouped thirty-five countries into four regional "clubs" — "Core, Rich European Offshoots, European Periphery, and LDCs-the country members of which are: 4 members of the industrial Core (France, Germany, UK, US); 7 rich European Offshoots (Argentina, Australia, Canada, Chile, Cuba, New Zealand, Uruguay); 10 from the European Periphery (Austria-Hungary, Denmark, Greece, Italy, Norway, Portugal, Russia, Serbia, Spain, Sweden); and 14 less developed countries (LDCs) in Asia, the Mideast and Latin America (Brazil, Burma, Ceylon,

5 Clemens and Williamson (2002, p.1).

6 For the positive openness-fosters-growth theory see Harrison (1996), Bloom and Williamson (1998), Greenway, Morgan and Wright (2002).

7 Clemens and Williamson $(2002$, p. 7$)$.

8 Note that Brazilian data only begin in 1870. The authors in a few cases substituted data sets that they considered more detailed and accurate than those used in CW. 
China, Colombia, Egypt, India, Indonesia, Japan, Mexico, Peru, the Philippines, Siam, Turkey)". ${ }^{9}$ Obviously, these categories apply to the beginning of the period studied (1860-1998). CW concluded that protection was associated with growth before World War II for each of the clubs across the period 1860-1950. However, they do not generalize this result to all member countries in each club.

The four clubs present in CW (2002) had quite different levels of unweighted regional averages of "own tariffs" across the period beginning in 1865 until 1950. Taking the average tariff rate as the ratio between the total value of import duties and that of imports as the most convenient measure to assess openness across countries ${ }^{10}$, $\mathrm{CW}$ found that the four clubs present quite different levels of unweighted regional averages of "own tariffs" in the period 1865-1950. Before the First World War the rich offshoots were the most protected group, usually above 20\%. The European periphery fluctuated from 10 to $20 \%$, while the core group was always below $15 \%$. Although the LDCs group was also below the 15\% level until the 1890s, they increased their average protection from then to the First World War, almost reaching the protection level of the rich offshoots. ${ }^{11}$ In fact, the average Latin American rates were far higher than those of the LDC group as a whole. ${ }^{12}$

Turning to Portugal and Brazil, we note that although major differences separate the two countries' economies, such as the obvious differences of size and climate, many economic and cultural traits link the two countries. Portugal, like Brazil, had a low growth rate of GDP per capita in the latter nineteenth century, and was near the bottom of the European periphery in that period. Beyond the common language, religion, and historical traditions of Portugal and Brazil, there was the important fact that they shared very similar constitutions during most of the $19^{\text {th }}$ century. Both charters were "granted" by the same man, who was Emperor of Brazil (as Pedro I) and subsequently King of Portugal (as Pedro IV). The two countries were also bound by strong economic ties in the nineteenth and early twentieth centuries-most obviously through Portuguese emigration to Brazil, which produced remittances of great importance in Portugal's balance of trade, but also through commerce itself (the sale of tropical products to Portugal in exchange for industrial and Mediterranean goods). These links are necessarily ignored in a cross-section analysis for a data panel. A significant difference between the two is the role of Brazil's tropical exports as a leading reason for its dependence on international

9 Clemens and Williamson (2002, p. 3).

10 "Among the explicit policy measures of openness available, the average tariff rate is by far the most homogenous protection measure and the easiest to collect across countries and over time," according to John $\mathrm{H}$. Coatsworth and Jeffrey G. Williamson, Always Protectionist? Latin American Tariffs from Independence to Great Depression, Journal of Latin American Studies, p. 207, May 2004.

11 Clemens and Williamson (2002, Figure 2).

12 Coatsworth and Williamson (2004); Rubio (2006). 
markets and consequent volatility in economic performance, while Portugal never exported enough to compensate for her imports. ${ }^{13}$

In the case of Brazil, the country began its national experience with a low tariff (15\%) that had been forced on both Brazil and Portugal by Britain in 1810, while Brazil was still a Portuguese colony. Brazil asserted its independence in commercial policy in 1844, upon the expiration of the treaty with Britain, roughly doubling the average tariff to about $30 \%$. In the period of the Belle Epoque, when Latin America led the world in high tariffs, only Colombia surpassed Brazil's tariff levels, which peaked at $40 \%$ in the decade 1900-1909, the same decade in which Brazil doubled it exports per capita ${ }^{14}$. Brazil's dependence on customs duties is ironic, in that the prevailing rhetoric by that time, most forcefully expressed by Finance Minister Joaquim Murtinho (1898-1902), was that of comparative (or absolute) advantage. Murtinho would do nothing for "artificial" industries (manufacturing) in the financial crisis of 1901-1902 because he believed that equal treatment of all economic activities by the state would amount to "socialism."15

As for Portugal, it raised its customs in 1837 , although the full impact on trade came only with the new treaty with Britain, signed in 1842. Tariffs remained high in the nineteenth century although a free trade philosophy was concurrently defended in intellectual circles and in the Parliament. ${ }^{16}$ Pereira (1983) advanced the view that relatively free trade prevailed in Portugal after 1852, when a new tariff system was introduced in line with the liberal ideology of the Regenerador Party. Such policy produced low growth rates and persistent trade deficits during the rest of the century. Reis (1984 and 1993) disagrees because, although political ideology could be described as liberal and favourable to free trade, Portuguese average tariffs were high throughout the second half of the century. He even argues that if a higher level of protection had been introduced, the impact on growth would have been slight, because the small size of the domestic market would have virtually ruled out import substitution. ${ }^{17}$ This line of reasoning led to the prevailing idea that "the simplest means of raising real revenue per capita would have been increasing 'foreign dependence' (...) as happened in other European countries". ${ }^{18}$

For CW, trade partners may belong to the same economic "clubs" or not. It is more common for partners to belong to different regions or clubs, a fact that explains the

13 For Brazil, see Goldsmith, (1986, p. 14). For Portugal, Mata (2002, p. 54-55).

14 Data from Clemens-Williamson appendix; Rubio (2006, p. 7) (on Brazilian exports).

15 Murtinho (n.d, p. Xiii).

16 Matta (2006a).

17 Reis (1993a, p 18-20).

18 Reis (1993a, p. 270). More recently, Fontoura and Valério (2000) also contradict Pereira (1983) because "during the period of intentional freer trade [1852-1890s] economic growth benefited (...); [but] during the period of intentional protectionism, economic growth was handicapped” (p. 185-186). 
strong variation of the average tariffs within the clubs. The intent of this paper is to examine the CW thesis on tariff reversal for two countries in different clubs.

As Figure I shows, both Brazil and Portugal experienced similar levels of tariff protection. Since Brazil was also an important trading partner for Portugal, the similar path of the average tariff in both countries merits discussion.

\section{FIGURE I - AVER AGE TARIFF (RATIO BETWEEN THE TOTAL VALUE OF IMPORT DUTIES AND THAT OF IMPORTS) Unit: Percentage}

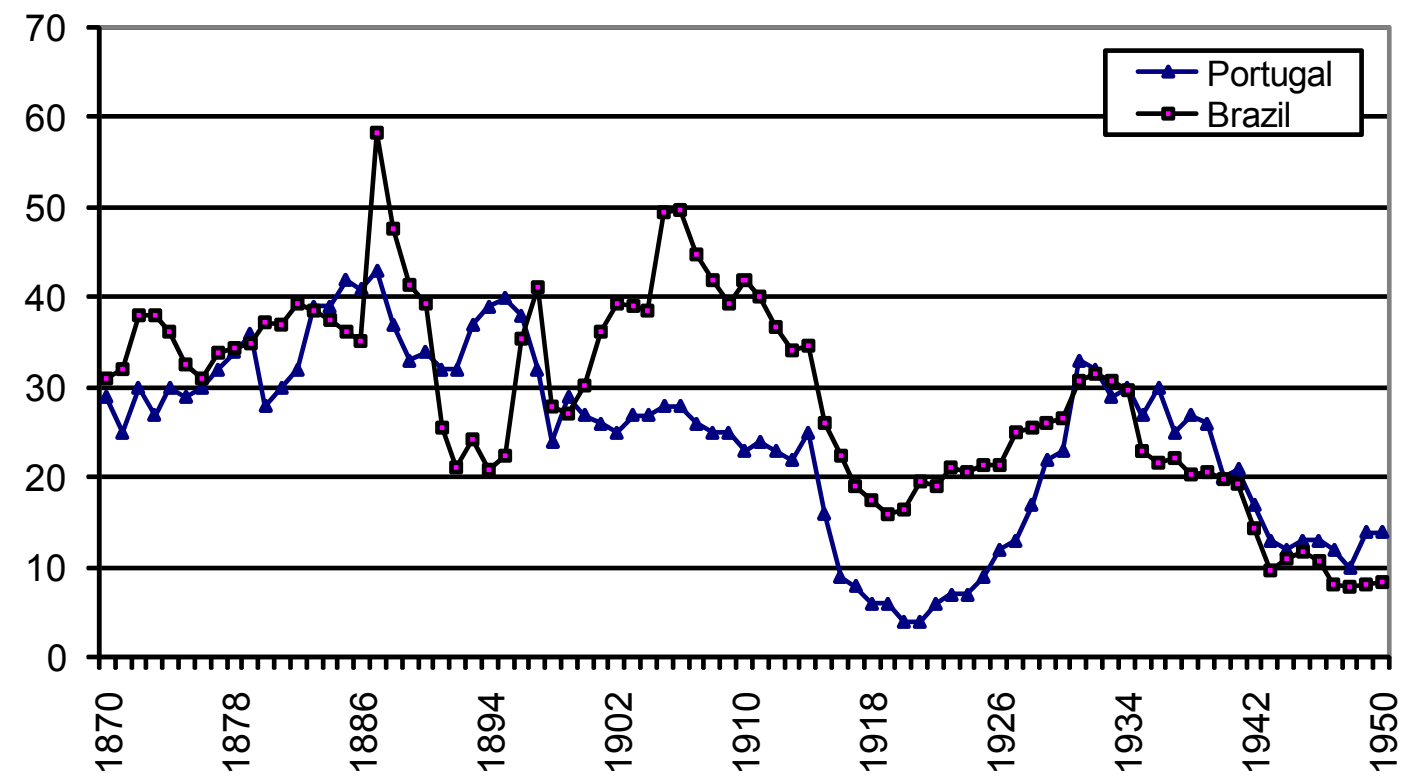

In both countries big decreases occurred in three periods: late 1880s-early $90 \mathrm{~s}$, 1914-30 grosso modo, ${ }^{19}$ and late 1930s-50. This means that main declines tended to occur in association with the global crisis of the 1890s and the two world wars and the Great Depression; they were in great measure a consequence of changes in the price level. (Brazil's wider swings are associated with the monocultural dependence on coffee prices.) Most of the tariffs were specific duties, expressed in monetary values per kilo or ton, for example. Sharp increases in prices inflated the value of imports in the denominator of the fraction used to estimate the average tariff. Thus the impact of inflations during the two world wars was spectacular in diminishing the average tariff both in Brazil and Portugal, as happened in many countries around

19 In Brazil, the fall of customs revenues as a share of the value of imports actually begins after 1906, and results from a rising level of inflation under President Afonso Pena. His two predecessors during 1898-1906 had successfully pursued orthodox financial policies to satisfy Brazil's main creditor, the Rothschild Bank. On the rate of inflation, see E. Reis (2002, unpaginated graph 2). 
the world. ${ }^{20}$ At the same time, each country's partners' tariffs influenced the tariff rates of Brazil and Portugal, as an international game was being played. So, the world environment matters for individual countries, as $\mathrm{CW}$ found for their clubs.

In the remainder of the paper, we will examine the effects of tariffs on growth in our two case studies. Detailed scrutiny of individual countries can show instructive similarities and contrasts between the national experiences in tariff reversal, even when the two countries had comparable levels of protection.

Before entering into the details, however, it is necessary to consider the quality of the data. Figures for Brazilian economic growth in CW are those of Maddison (2001), a source that in turn is based on Goldsmith for the years 1850-1900 (1986). ${ }^{21}$ Several scholars have argued that Goldsmith's data on growth are not reliable, ${ }^{22}$ and he does not provide the sources for the figures he uses. It seems that the best data are still those of Cláudio Contador and Cláudio Haddad, hereafter cited as $\mathrm{CH} .{ }^{23} \mathrm{CH}$ data exhibits more variability than that of Clemens and Williamson (derived from Goldsmith), especially before 1900, and hence it was preferred to the CW data. The $\mathrm{CH}$ data have been corrected for a typographic error. Figures for Portuguese GDP, as in CW, come from Neves [1994], after conversion to 1990 USA dollars. ${ }^{24}$ However, Valério's Portuguese Historical Statistics offers better data for railways, labor force, and arable land than those in CW, so we use them for Portugal. ${ }^{25}$

\section{FRAMING THE EFFECTS OF PROTECTION ON GROWTH}

So, what is the role of the country's own average tariff on long-run economic growth in Portugal and Brazil?

Using macro-econometric analysis of time series to explore the connections between protection and growth, one must tread warily. The theoretical endeavors to explain a positive correlation between tariffs and growth is presented in the ClemensWilliamson's paper, using several arguments.

20 As noted in CW.

21 See Maddison (2001, p. 143).

22 Personal communications from Luis Catão, William Summerhill, and Gail Triner. Superimposing the CW estimate of Brazilian growth and that of Contador and Haddad shows much greater annual variability in the latter, and growth before 1900 in the CW graph is almost zero from 1870 to 1899. From this fact one might infer that the pre-1900 data in CW were simply a backward projection by Goldsmith. The two series behave similarly in the period 1900-1950. See Appendix 2.

23 Contador and Haddad (1975). Estimates of the size of the national product were based on imports and exports, government expenditures after 1901, electrical energy installed after 1883, and consumption of cement.

24 Clemens and Williamson (2002, p. A-9).

25 Valério (2001). 
First of all, co-ordination of tariff policy among trading partners must be considered. If countries do not coordinate their tariff policy, they face a prisoner's dilemma, as CW assert: Each will be better off in the absence of tariffs, but if coordination is not achieved, each country will seek its privately optimal level of tariffs, even when the result is collectively sub-optimal (because growth and trade would be greater if no trade barriers existed at all). Before the Second World War only a few countries achieved co-ordination (and for limited periods), leading to the possibility that tariffs and growth were positively correlated in countries that adopted tariffs. Therefore, the model needs to include not only the variable "own tariff", but also the variable "partners' tariff" 26 . Note that Coatsworth and Williamson even discuss whether "Latin American governments pursued protectionist policies because they learned through trial and error that high tariffs promote economic growth." 27

Clemens and Williamson also consider that reforms in national tariff systems may have targeted different goods with differently-shaped supply and demand curves and thus different tariff-related benefits and costs. Moreover, in a long-run perspective for industrialization, distortions in costs may alter terms-of-trade benefits, affecting the relation between own tariff and own performance that may explain a historical reversal. Protection policies may also include moves from tariff to non-tariff barriers; moreover, these shifts may be "bundled" with significant changes in domestic fiscal systems. Such policy restructuring may also help explain reversal paradoxes. Furthermore, other changes in policies or conditions affecting growth also occurred massively, such as economic and institutional changes resulting from decolonization. But this situation did not affect Portugal and Brazil in the period under study; therefore, it may be discarded.

Finally, the effective distance to the main trade partners must be included, to take into account the effects of distance in international trade. Following CW, we introduce this consideration for Portugal and Brazil. Naturally, commercial relations with more distant partners are negatively affected by higher costs of transportation. In addition, most of the studies of the effects of tariffs on growth disregard distance. Especially in the pre-1914 era, distance was important, because this "tyranny of distance” worked as a natural tariff, provoking distortions in trade and growth. The CW model includes the "average distance to trading partners", since distance may "contaminate" the influence of tariffs on trade and growth. On the other hand, underdeveloped countries such as Portugal and Brazil before World War II could

26 Following CW, "partners' tariff” includes the weighted averages of the five most important trading partners: "The index of tariffs in principal trading partners is calculated as the weighted average of own tariffs in the four or five countries to which the country in question exported the largest absolute value of goods... The weights are the absolute value of exports that went to each of said partners. These partner export figures are taken from Mitchell... [1992, 1993, 1998]. In all cases, the vast majority of each country's exports are accounted for by exports to these principal trading partners.” (CLEMENS; WILLIAMSON, 2002, p. A-16).

27 Coatsworth and Williamson (2004, p. 207). 
reap advantages from trading with more distant nations rather than neighbouring ones, if the distant economies were strongly complementary (e.g., offering industrial products for tropical goods). However, a reversal paradox may also have occurred because the great fall in transport prices in the late $19^{\text {th }}$ century produced lower final prices, and thereby greatly intensified world trade among all regions. Domestic markets (particularly in urban centers) and export shares cannot be omitted in expressing the institutional dimensions of the industrialization process in some of the partners. Capital, land-labor ratios and education, are the variables used to capture the effects of industrialization.

In short, the effects of tariffs on economic growth are clearly a complex phenomenon. In considering both supply-side and demand-side lines of reasoning in recent literature, if one moves to the economics of growth, some of the variables incorporated in the model embody aspects of culture, and others, technology. The role of such embodied aspects is necessarily controversial. International economics since Romer (1986) connects the development of endogenous models of growth to neoclassical theories of development that include Solowian perspectives. Therefore, aspects such as education, capital, along with urbanization explain how growth depends not only on factors of production, but also on the quality of these factors. ${ }^{28}$ Furthermore, because the sharp fall in the average tariff rates during the two world wars was related to inflation and was exogenous to the tariff-growth paradox, we follow $\mathrm{CW}$ and omit the war years in the estimations. ${ }^{29}$

The model employed is the following:

$$
\begin{aligned}
& \text { GROWTH }=\mathrm{C}+\text { a. }(\text { TARIFF })+\text { b. }(\text { PTNRTAR })+\text { c. }(\text { TARIFF*PTNRTAR) } \\
& + \text { d. }(\text { EFFDIST })+\text { e. }(\text { TARIFF*EFFDIST })+\text { f. }(\text { KIDSKOOLGR }(-1))+ \\
& \text { g. }(\text { RAILWAYSGR }(-1))+\text { h. }(\text { EXPORTSGR }(-1))+\text { i. (EXPORTS })+j . \\
& \text { D }(\text { LANDLABOR })+\text { l. }(\text { URBGR }(-1))
\end{aligned}
$$

where, using the terms employed by CW, GROWTH means the country's own GDP per capita growth in order to control for the size of population. TARIFF means the country's own average tariff, to proxy protection; ${ }^{30}$ PTNRTAR means the main partners' average tariff; ${ }^{31}$ EFFDIST means the effective average distance from a giv-

28 Krugman (1991).

29 Defined here as 1914-1918, and 1939-1945.

30 Average tariff rates (in \%) were taken from $\mathrm{CW}$ and "are calculated as the total revenue from import duties divided by the value of total imports in the same year" (CLEMENS ; WILLIAMSON, 2002, p. A-1).

31 The index of tariffs in principal trading partners (in \%) was taken from CW and "is calculated as the weighted average of own tariffs in the four or five countries to which the country in question exported the largest absolute value of goods" (CLEMENS ; WILLIAMSON , 2002, p. A-16). 
en country's capital to the main partners' capital cities; ${ }^{32}$ KIDSKOOLGR means the growth rate of schooling, to proxy education and human capital; ${ }^{33}$ RAILWAYSGR means the growth of the rail $\mathrm{km}$ network, to proxy the available physical capital in the economy; ${ }^{34}$ EXPORTS means export share and EXPORTSGR means exports' growth; ${ }^{35}$ LANDLABOR means the land-labor ratio; ${ }^{36}$ and URBGR means the country's own urbanization rate, to proxy domestic demand, considering 50 thousand inhabitants as the bound to define an urban centre; ${ }^{37}$ TARIFF $^{*}$ PTNRTAR captures the joint effect of domestic tariffs and partners' tariffs; and TARIFF* EFFDIST captures the joint effect of domestic tariffs and effective distance to the capital city of the main trade partner.

The growth of KIDSKOOL, RAILWAYS, EXPORTSGR and URBANIZATION are lagged by one year to eliminate the possibility of endogeneity of these variables. Otherwise, it could be debated whether growth in per capita GDP caused an increase in these variables, or vice versa.

We controlled for autocorrelation by estimating an autoregressive model, as it is a common finding in time series regressions that residuals are correlated with their own lagged values. Serial correlation violates the standard assumption of regression theory because OLS is no longer efficient among linear estimators. The BreuschGodfrey Serial Correlation LM Test was used to detect serial correlation. The stationarity condition was tested by ascertaining that the inverted roots of the autoregressive processes lie within the unit circle.

To test the tariff reversal hypothesis, estimations were made for two sub-periodsthe pre-World War I years and the interwar years.

32 Effective Distance from trading partners was taken from CW "calculated as the product of two quantities. The first quantity is the average distance from the capital city of the country in question to the capital cities of its principal trading partners, weighted by the value of exports going to each of those partners in the year in question” (CLEMENS ; WILLIAMSON, 2002, p. A-12).

33 Again, we use the method of CW: "Primary school enrollment rates for those of school age are calculated by dividing per capita primary enrollment rates by the fraction of the population under the age of 14 . The fraction of the population under the age of 14 is calculated from the appropriate editions of Mitchell (1992, 1993, 1998), where the population distributions by age are provided for census years" (CLEMENS; WILLIAMSON, 2002 , p. A-15).

34 From Valério (2001), for Portugal and CW for Brazil.

35 The export share is taken from $\mathrm{CW}$ and "is calculated as the ratio of exports to national income" (CLEMENS; WILLIAMSON, 2002 , p. A-11).

36 The land-labor ratio was taken from Valério (2001) for Portugal, and CW for Brazil: It "is calculated by dividing total area of arable (food) crops in hectares by labor force” (CLEMENS ; WILLIAMSON, 2002, p. A-14).

37 It was taken from $\mathrm{CW}$, as the ratio between the population living in centers above 50,000 inhabitants and total population. 
The model specification shows that higher domestic tariffs were significantly correlated with an increase in GDP for both Portugal and Brazil before 1914. Testing the CW claim by estimating the model for the period before World War I in Tables $\mathrm{l}$ and 2 of the Appendix, one may say that both the Portuguese and Brazilian cases confirm CW's conclusion that protection was favourable to growth. Tariffs are a significant variable for the period before World War I. They mattered for growth, and the coefficient is positive. Thus a small European peripheral country employing a high level of protection - Portugal — and a similarly protectionist large South American country - Brazil - experienced growth, just as did the free trade-oriented countries of the European core.

According to the estimated results of Tables 1 and 2, partners' tariffs were also significant and positively correlated with an increase in the GDPs of Portugal and Brazil before 1914. Indeed, in both the Brazilian and Portuguese cases, partners' tariff was twice as important as each country's own tariff. Note that before World War I the average "own tariff" in the core European countries fluctuated from about 12 to $18 \%$, and co-ordination was achieved under the gold-standard regime. Its automatic rules on international trade and the existence of an international financial leader in the system, England, brought stability to the whole trading framework. The adoption of higher tariffs by the rich European offshoots did not change the broad free trade environment prevailing in the second half of the nineteenth century. ${ }^{38}$ Even when tariffs in some core countries increased in the 1880s and 1890s, the average tariff for the whole core did not change radically. In such a world, less developed countries such as Portugal and Brazil could gain from maintaining high average "own tariffs", as they could enjoy a privately unconditionally optimal situation. In the case of Brazil, the single main trading partner was the United States, a high tariff country, but the U.S. did not significantly retaliate by raising tariffs against Brazil (see below). Moreover, although the free trade philosophy was widely defended in the Portuguese and Brazilian Parliaments, budgetary necessity put strong pressures on the governments to keep tariffs high; before World War I tariffs provided about one-third of central government revenue in Portugal and between half and twothirds of revenue in Brazil. ${ }^{39}$

In Brazil, during the Empire (1822-1889) and the Republic that followed, as well as in Portugal, under monarchy and Republic (from 1910), specific tariffs were used in

38 It is well-known, of course, that the movement toward free trade receded after the Great Depression began in 1873 .

39 For Portugal, Mata (1993, p. 131); For Brazil, Fishlow (1972, p. 318) (2/3 of government income in the 1890s) and Rubio (2006, p. 29) (54\% in 1900 and 1910). 
preference to ad valorem rates, because the latter were subject to greater fraud, owing to the discretion necessarily allowed to customs agents. ${ }^{40}$ This preference produced a great diminution of the value of tariffs in periods of rapid inflation, such as that during Brazil's Encilhamento ("saddling up") euphoria in 1889-91, and again toward the end of World War I. The exchange rate also affected the real value of customs duties as a de facto source of protection. Beyond that, during the Brazilian Empire, tariffs sometimes had to be paid at an "official" specific rate which was higher than the real rate of exchange. For example, the João Alfredo Tariff of 1889 had a modal rate of $48 \%$ that rose to over $100 \%$ when "official" values were applied. In Portugal, a parallel case is the "Hunger Law" (Lei da Fome) on grains. ${ }^{41}$

Regarding distance, as noted above, the advantages of trade with distant regions arise from major differences in natural advantages that could overcome higher transport costs. For Portugal, the role of distant partners (including the USA) is clear, as the coefficient of distance in Table 1 shows, while trade with nearer partners had less importance. Portugal may have suffered retaliation for her high duties, as Table 1 indicates. The joint effect of Portuguese tariffs and distance was also detrimental to growth.

In the Brazilian case, and probably more broadly, growth was possible with high tariffs because Brazil's main trading partner, the United States, had the highest average tariff rate among the core countries. For Brazil's major export-coffee, of which Brazil supplied about $75 \%$ of world consumption around 1910 -demand was very price-inelastic, and the United States could have raised tariffs on this product without lowering consumption (within a certain range). In a recent econometric study, Abreu and Fernandes show that Brazil, as a price-maker in the world market for coffee, could affect the world price by a combination of export taxes, import taxes, and stockpiling. The tax on coffee exports was successfully passed through to foreign consumers. ${ }^{42}$

Even after the "valorization" program-the retention of coffee stocks to keep prices high (implemented in 1908) - the American government chose to apply its antimonopoly legislation rather than use the tariff route to retaliate against its trading partner. Table 2 confirms this effect, as TARIFF*EFFDIST is a non-significant variable. In any event, the U. S. action failed to lower the price of coffee more than temporarily, and Brazil had consistently higher tariffs than the United States until the mid-thirties, after which they were very similar. All the same, Brazil and Colombia, the Latin American nations with the highest average tariffs as a share of

40 Villela (2005, p. 46). We thank Werner Baer for bringing this study to our attention. The same point applied to other countries, as noted in CW.

41 Villela (2005, p.48); Reis (1984).

42 Abreu and Fernandes (2006, p. 21-22). 
the value of imports, apparently grew at a slower pace than those with lower rates within this high-tariff group. ${ }^{43}$

For Portugal, human capital proxied by education (CW's KIDSKOOL) is significant and negatively correlated to an increase in GDP; it was not significant for Brazil. This may appear to be a strange result. One should bear in mind, however, that studies on education stress that long periods (of about 30 years) are necessary to produce effects on growth, and the sample is short. ${ }^{44}$ Still, the significance of the variable for Portugal and its negative role may highlight a spurious relationship, or it may indicate the widespread use of children in economic activities.

As for capital, proxied by railway growth, the correlation with GDP growth doesn't achieve significance in Portugal, but in Brazil it was negatively correlated with growth. Why this occurred isn't clear, but it may mean that the payoff to investment for sunk capital had not yet occurred, or less likely, perhaps, that opening the territory to foreign products decreased the sale of local and regional products.

Regarding exports, tropical products in Brazil place that country in sharp contrast to Portugal. In Brazil, exports provided almost $19 \%$ of GDP in $1900 .{ }^{45}$ In fact the export character of the Brazilian economy and the modest exports of Portuguese Mediterranean crops are evident in comparing results of Tables 1 and 2. It seems that exports were an important force in Brazilian growth, while urbanization was an important element in Portuguese growth. Brazil's terms of trade took a secular turn downward after 1885, and there was continual pressure to raise tariffs to maintain government revenues. In addition, tariffs were seen as an instrument for promoting import substitution as early as the Alves Branco Tariff of $1844 .{ }^{46}$ However, there does not seem to have been any significant substitution effect until the period 1890 1913. ${ }^{47}$ Even then, the tariff played less of a role in protecting industry than did inflation and a resulting fall in the value of the Brazilian currency, especially in the early 1890s. ${ }^{48}$

According to neoclassical explanations, the improvement in the land-labor ratios of protected economies such as Portugal enhanced growth before World War I, a period when agricultural production was a leading economic activity. Yet we should recall how significant Portuguese emigration was during the second half of

43 Coatsworth and Williamson $(2004$, p. 231).

44 According to Bils and Klenow (1998, p. 1): "Even faster-growing countries have at most modestly flatter cross-sectional experience-earnings profiles, consistent with a minority role for the channel from the schooling to growth". For the two-way relationship between education and growth, see Islam (1995).

45 Franco (1990, p. 14).

46 For food processing-sugar in particular-plus wrought iron and textiles.

47 Villela $(2005$, p. 46$)$.

48 Fishlow (1972, p. 332). 
the nineteenth century for explaining the improvement of the land-labor ratio and productivity in the country. ${ }^{49}$ For Brazil, however, this variable was not significant in the pre-war period.

It should be noted that the sign and significance of these variables were found to be very robust to the inclusion or exclusion of other control variables. First of all, CW note that higher tariffs were associated with higher growth. ${ }^{50}$ They find a positive and significant relation between tariff and growth for the pre-World War I period after accounting for differences among the income-based "clubs." LDC set (Brazil's group), the coefficient of the tariff variable is small compared to the European periphery and the Core, i.e., almost one-fifth the magnitude. ${ }^{52}$ They find a robust positive coefficient for tariffs under alternative control variables, as we do for Brazil, but the magnitudes of coefficients are again very small for the LDC group compared to other groups. In summary, it seems that findings for Brazil here are much stronger than those of CW for the whole of their LDC club.

For Portugal, one might consider substituting Lains' foreign trade data (1995). However, Lains' figures stop at 1914 and are of questionable reliability, since they don't match other items of the Portuguese balance of payments. ${ }^{53}$ Using data on adult literacy rate (instead of the KIDSKOOL growth rate) was another possibility, although it was not collected annually. Reestimating the model, we found its sign was negative and not significant during the years before WWI and the R-square decreased marginally. In the period between the wars, the sign was positive and not significant. The KIDSKOOL growth rate was retained in the results presented here to preserve the strict comparability of results between the two countries, as the adult literacy rate is not available for Brazil, except in census years. Using different data for Portugal's GDP per capita from Maddison (2003), we reach similar conclusions on explaining growth and economic performance, pointing to the positive role of the domestic consumption for the performance of the Portuguese economy, a conclusion also reached by Justino $(1988,1989)$. Repeating the estimation to explain GDP confirms these results in a similar R-square value. The established thesis that more free trade would have contributed for Portuguese growth ${ }^{54}$ is not confirmed for the period before World War I. In the case of Brazil, substituting the CW data for GDP growth for those of Contador and Haddad also reveals a significant positive correlation between tariffs and growth.

49 Serrão (1974).

50 Clemens and Williamson (2002, p. 9 and Table 1).

51 See their Table 2.

52 Merely $0.0054(=0.0681-0.0627$, Table $2, \mathrm{CW})$, compared to -0.0147 for the European periphery, +0.0233 for the core.

53 Mata (2002).

54 Reis $(1984,1993)$. 
The novelty of the interwar period in studying the two national cases of Portugal and Brazil is the tariff reversal paradox for Brazil. As Tables 3 and 4 show tariffs continued to be a significant variable for growth in both countries, yet Portugal seems to have preserved the benefits of protection, while in Brazil tariffs and partners' tariffs became detrimental for the growth of the national economy. In the 1930s extensive import substitution took place in Brazil, during which time GDP grew almost $6 \%$ per year. In that decade it was rising domestic demand more than the tariff that drove industrial growth. ${ }^{55}$

In the 1920s and 1930s protection became the rule in international markets, but small closed economies, such as Portugal's, were less affected. ${ }^{56}$ Self-sufficiency was the rule. According to Table 3, the increased tariffs of Portugal's partners were beneficial for the Portuguese economy, a result that may be accepted only if those tariffs were mainly erected against other partners and not as a retaliation against the high Portuguese tariffs. Nonetheless, some losses occurred from the interaction of domestic tariffs and partners' tariffs, as neoclassical theories and game theories suggest.

As for distance, for Portugal the advantages of trade with distant regions prevailed again over the greater transport costs to distant partners. Still, in line with neoclassical interpretations, the joint effect of Portuguese tariffs and distance was detrimental for growth.

The Brazilian terms of trade took a turn down again in the 1920s and 1930s, and in the same period exports became a negative variable for Brazilian growth, while export growth was positive. As noted, the role of tropical exports sharply distinguishes Brazil from Portugal. In fact, the export character of the Brazilian economy led to a detrimental dependence on foreign demand. In the prewar period, some of the import substitution was in food production, but more important was the rise of a cotton textile industry in the early 1890s. ${ }^{57}$ After World War I, higher partner's tariffs were also negatively associated with Brazil's growth. All this is in line with the neoclassical explanation of openness and growth. However, there were some gains for the Brazilian economy if both the home country and the trading partners maintained higher tariffs, as the positive coefficient of the joint effect of domestic

55 Fishlow (1980, p. 104). However, Suzigan believes that in the 1930s falling exchange rate and exchange controls were more important forms of protection than tariffs for import substitution. (SUZIGAN, 1986, p. 351-352).

56 Rosas (1987).

57 Leff (1982, p. 149); Fishlow (1972, p. 312-313). 
and partners' tariffs shows in Table $4 .{ }^{58}$ Once more Abreu and Fernandes (2006) confirm that retaliation from the USA against Brazil (and Chile) did not harm these national economies: (...) United States could not have exploited fully its market position due to the fact that it faced an elastic demand curve at the margin as it was a price taker for food exports. ${ }^{59}$

CW grouped Brazil with the LDCs, but Coatsworth and Williamson argue that all the Latin American countries in the Clemens-Williamson sample, regardless of the "club" they were members of, as a group had the highest tariffs in the world from the 1860s until the 1920s. ${ }^{60}$ Nonetheless, the Latin American nations grew at a rapid rate in the "classic" era of export-led growth until World War I. In the period between 1919 and 1939, Brazil's economy followed a neoclassical growth path. Increased physical capital (proxied by railway growth) and higher land-labor ratios resulting from the introduction of the mechanization of agriculture were positively correlated with GDP, as technical progress could lead to a Schumpeterian path of growth. The improvement in the land-labor ratio was also related to the closed-door policy for immigration that, in turn, may have stimulated investment in agricultural machinery. ${ }^{61}$ It is an irony that the neoclassical path was taken in a period of greater state intervention, excepting tariff collection.

For Brazil, the distance from the trading partners became significant and negative after World War I. It may be that Brazil increased its trade with nearby partners rather than the United States and Europe. But the interaction of tariffs and distance was slightly positive.

Tables 3 for Portugal and 4 for Brazil show railway growth as a significant factor in explaining GDP growth. Agrarian countries benefited from opening their interior areas to investments from capital-rich nations. One should recognize that in neither country had the present-day rail network been completed by the First World War. After 1920 the density of the rail network continued to grow in both countries, and the two national markets became better integrated internally. ${ }^{62}$

58 The result also stands for the period before the Great Depression in a simplified version of the model that preserves the main variables only, because of the small number of observations. The variable is relevant and the coefficient is positive.

59 p. 20.

60 Coatsworth and Williamson (2004, p. 206). As noted above on p. 4-5, for CW, Argentina, Uruguay, Cuba, and Chile were "rich European offshoots" in the late $19^{\text {th }}$ century, while Brazil, Colombia, Mexico, and Peru were LDCs.

61 After 1934, Brazil introduced quotas for immigrants based on nationality.

62 Rosas (1987); Ludwig (1985, p. 242). 
No other variables were significant in the Portuguese case. In the Brazilian case, the growth of schooling was negatively correlated and significant. Again, it may be that the economy primarily required unskilled labour, or that the payoff to investment in education was still in the future.

Note that R-square reveals good adjustment for the estimations in both countries.

How robust are the results obtained here, for both the period before WWI and the interwar years?

A model using moving averages was also estimated; however, it did not produce satisfactory results in terms of statistical significance of the coefficients. We therefore used an autoregressive model, the results of which are presented here. ${ }^{63}$ As recent international economics seeks to develop endogenous models of growth, it might be argued that most of the explanatory power of our model may be coming from the auto-correlated nature of growth. To check this argument, we ran tests for the joint significance of coefficients of the explanatory variables, and the results are available in the Appendix (Tables 5, 6, 7 and 8). They show that coefficients of the explanatory variables are significant and do explain the variation in growth, after autocorrelation is controlled for both countries in the two periods. We are therefore able to reject the null hypothesis that all the coefficients of the explanatory variables are jointly zero after accounting for lagged dependence in the growth variable. The model therefore has significant explanatory power.

Results are quite clear. The CW methodology, using panel data, is much "thinner" than ours because cross-section analysis only captures long-term trends for the whole set of countries. By contrast, this paper demonstrates for Brazil and Portugal how growth reacts to each variable in the two periods. Brazil, contrary to the CW findings, disconfirms the contention that tariffs were positive for growth after the First World War. These econometric findings should put an end to some of the hoary polemics among economic historians of the two countries and, most importantly, they can shed a new light on the theoretical approaches on the role of protection for growth.

The paper confirms the need of formal models that include international political contexts, to analyze tariff policy adoption and its effects on growth. It calls attention

63 To measure long-term growth we would need to account for long-term impacts of other variables too, and we do not have long enough time series for Portugal and Brazil. 
to long-run changes in the levels of modernization, mechanization or industrialization in trading partners for considering the effects on the costs and benefits of tariffs for their growth. Following $\mathrm{CW}$, this paper shows the importance of co-ordination and retaliation, and should be a stimulus to the use of game theory approaches to the relationship between tariffs and growth. It exemplifies a situation of decreased international market power that tended to increase the ratio of distortion costs to modest terms-of-trade benefits for Brazil in the interwar period. The paper illustrates how important were distance and the cost of transport.

The positive association between tariffs and growth does not necessarily mean that tariffs were purposely and principally used to foster growth, although the role of tariffs in growth was often bound up in ideologies and political doctrines. It is true that in Portugal and Brazil by the second half of the nineteenth century - as in many other countries of the periphery - the elites were aware of the economic success of the core nations and their offshoots. Portugal and Brazil now began to face up to the need for modernization. Even so, tariffs were collected primarily to supply the government with income. ${ }^{64}$ First of all, customs duties allowed the government to collect large revenues with very low costs, as only a small number of public servants were needed. Secondly, duties were a relatively reliable source of revenue, particularly when fluctuations in domestic economic activities decreased the returns from other taxes. Moreover, tariffs were a hidden tax, as the public did not distinguish them in the prices they paid for imported goods. Indeed, a good item for a future research agenda is exploring the extent to which this "fiscal amnesia" was important from a political perspective. Consequently, customs were an indispensable element in the Portuguese and Brazilian budgets. ${ }^{65}$ One may also concede that the high tariffs in both countries could result from pressures in parliament to protect certain economic activities, or from defined ideological programs. Both aspects were relevant for Brazil and Portugal. In fact, parliamentary sources offer long discourses on this issue, most of the time using erudite arguments derived from the late mercantilist writers, the classical authors, or the German Historical School. ${ }^{66}$ The benefits of competitiveness were countered by the contention that the low level of development required state intervention, or by direct references to the infant industry argument, an issue that future researchers will want to confirm or disconfirm. Cliometric applications of the theoretical arguments will help to explain the level of tariffs in each of the two countries, though the central concern was sufficient revenue for government operations. In particular, we need research on the price-elasticity of demand for imports in the two countries. In Brazil, one may suppose that the 
skewing of income distribution had an effect on the high level of imports, despite the country's high tariffs.

The First World War was a turning point. In the 1920s Great Britain tried to restore the gold-standard system, which provided the international framework for co-operation. Yet success was limited, even if both Portugal and Brazil temporarily returned to the gold standard. There was no single dominant trading partner for the international system in the interwar years, as Britain had been before $1914 .^{67}$ After 1930, protectionism rose in all countries. The collapse of international trade led to increasingly closed, self-sufficient economies. The Great Depression affected Brazil, the large exporter country, more than Portugal, in its transformative effects on the country's economic structure. Yet as late as 1937, the sudden recession in the United States hit Brazil hard, contributing to the crisis that brought about Vargas's Estado Novo dictatorship. Portugal by contrast had to make a smaller adjustment, reorienting its economy toward trade with its African colonies.

Of course, the Second World War separates two worlds, with respect to international trade. As the Portuguese experience from the 1960s to the 1990s shows, generalized free trade, supra-national institutions, and more intensive globalization seems to produce more vigorous growth than protectionist policies.

\section{REFERENCES}

ABREU, Marcelo de Paiva; FERNANDES, Felipe Tãmega. Market power and commodity prices: Brazil, Chile and the United States, 1820s-1930. $14^{\text {th }}$ Congress of the International Economic History Association. Helsinki, Finland, August, 2006, Session 42. Available at: <http://www.helsinki.fi/iehc2006/papers2/ Abreu.pdf $>$.

BAUER, R. I. Pool; DEXTER, L. American Business and Public Policy. Chicago: Aldine Atherton, 1972.

BILS, Mark; KLENOW, Peter J. Does schooling cause growth or the other way around? NBER Working Paper 6393, 1998. Available at: < http://www.nber. org/papers/w6393.pdf $>$.

BLATTMAN, Christopher; HWANG, Jason; WILLIAMSON, Jeffrey. The impact of the terms of trade on economic development in the periphery, 1870-1939: Volatility and secular change, NBER Working Paper 10600, June 2004.

BLOOM, David; WILLIAMSON, Jeffrey. Demographic transitions and economic miracles in emerging Asia. World Bank Economic Review, 12, p. 419-455, Sept.1998.

67 Kindleberger (1984). 
CABRAL, Manuel Vilaverde. O desenvolvimento do capitalismo em Portugal no século XIX. Lisbon: A Regra do Jogo, 1981.

- Portugal na alvorada do século $X X$ : forças sociais, poder político, crescimento econômico de 1890 a 1914. Lisbon: A Regra do Jogo, 1979.

CASTRO, Armando. A revolução industrial em Portugal no século XIX. Lisbon: Limiar, 1978.

CLEMENS, Michael A.; WILLIAMSON, Jeffrey G. Why did tariff-growth correlation reverse after 1950? NBER Working Paper 9181, September 2002.

CONTADOR, Cláudio R.; HADDAD, Cláudio L. Produto real, moeda e preços: A experiência brasileira no periodo 1861-1970. Revista Brasileira de Estatística, v. 36, n. 143, p. 407-440, jul.-set. 1975.

COATSWORTH, John H.; WILLIAMSON, Jeffrey G. Always protectionist? Latin American tariffs from Independence to Great Depression. Journal of Latin American Studies 36, p. 205- 232, 2004.

DINOPOULOS, Elias; SYROPOULOS, Constantinos. Tariffs and Schumpeterian growth. Journal of International Economics, 42, p. 425-452, 1997.

FISHLOW, Albert. Brazilian development in long-term perspective. American Economic Review, v. 70, n. 2, p. 102-108, May 1980. Papers and proceedings.

. Origins and consequences of import substitution in Brazil. In: DI MARCO, Luis Eugenio (ed.). International Economics and Development: Essays in honor of Raúl Prebisch. New York: Academic Press, p. 311-365, 1972.

FONTOURA, Paula; VALÉRIO, Nuno. Foreign economic relations and economic growth in Portugal: a long term view. Economies et Sociétés, 3, p. 175-206, 2000 .

FRANCO, Gustavo. A primeira década republicana. In: ABREU, Marcelo de Paiva (ed.). A ordem do progresso: cem anos de politica econômica republicana 1889-1989. Rio de Janeiro: Campus, 1990, p.11-30.

FURTADO, Celso. Formação econômica do Brasil. São Paulo: Fundo de Cultura, 1976.

GOLDSMITH, Raymond W. Desenvolvimento financeiro sob um século de inflação. São Paulo: Editora Harper \& Row do Brasil. Technical revision by Cláudio R. Contador and Pedro Carvalho de Mello, 1986.

GREENWAY, David; MORGAN,Wyn; WRIGHT, Peter. Trade liberalisation and growth in developing countries. Journal of Development Economics, 67, p. 229$244,2002$.

HARRISON, Ann. Openness and growth: a time series, cross-country analysis for developing countries. Journal of Development Economics, 48, p. 419-447, 1996.

ISLAM, Nazrul. Growth empirics: a panel data approach. Quarterly Journal of Economics, v. 110, n. 4, p. 1127-1170, 1995. 
JUSTINO, David . A formação do espaço económico nacional, Portugal 1810-1913. Lisbon: Vega, 1988-1989.

KINDLEBERGER, Charles P. A financial history of Western Europe. London: George Allen \& Unwin, 1984.

LAINS, Pedro. Exportações portuguesas, 1850-1913: A tese da dependência revisitada. Análise Social, v. XXII, n. 91, p. 381-419, 1986.

O proteccionismo em Portugal (1842-1913): um caso mal sucedido de industrialização concorrencial. Análise Social, v. XXIII, n. 97, p. 481-503, 1987.

A economia portuguesa no século XX - Lisbon: Imprensa Nacional Casa da Moeda, 1995.

LEFF, Nathaniel. Underdevelopment and development in Brazil, Economic Structure and Change, 1822-1947, vol I., London: George Allen \& Unwin, 1982.

LUDWIG, Armin K. Brazil: a handbook of historical statistics. Boston, Mass.: G. K. Hall, 1985.

MADDISON, Angus. Monitoring the world economy 1820-199. Paris: OECD, 1995.

. The world economy : a millennial perspective, Paris: OCDE, 2001.

. The world economy: historical statistics. Paris: OECD, 2003.

MARQUES, A. H. Oliveira; SERRÃO, Joel. Agricultura pecuária e pescas. In: Nova História de Portugal, v. XI, Lisbon: Presença, 1991.

MARTINS, Joaquim Pedro de Oliveira. História de Portugal. Lisbon: Guimarães Editores, 1972.

MATA, Maria Eugénia. As finanças públicas portuguesas da Regeneração à Primeira Guerra Mundial. Lisbon, Banco de Portugal, Economic History Series, n. 4 , 1993.

. As crises financeiras no Portugal contemporâneo: uma perspectiva de conjunto. In: Crises em Portugal nos séculos XIX e XX. Lisbon, Centro de História da Universidade de Lisboa, 2002, p. 33-55.

- As lentas transformações fiscais da época da Regeneração. As Finanças Públicas no Parlamento Português, v. 2 , Lisbon: Assembleia da República, 2006a.

- A discussão parlamentar dos orçamentos da Regeneração à República. As finanças públicas no parlamento português, v. 3, Lisbon: Assembleia da República, $2006 b$.

MILNER, Helen V. The political economy of international trade. Anmual Review of Political Science, v. 2, p. 91-114, June 1999.

MITCHELL, Brian R International Historical Statistics: Europe 1750-1988; ... The Americas, 1750-1988; ...Africa, Asia \& Oceania, 1750-1993. New York: Stockton Press, 1992, 1993, 1998. 
MURTINHO, Joaquim [Ministro da Fazenda]. Relatório apresentado ao Presidente da República dos Estados Unidos do Brasil no ano de 1899. Rio de Janeiro: Imprensa Nacional, n.d.

NEVES, João César. The portuguese economy: a picture in figures, XIX and XX centuries long-term series. Lisbon: Universidade Católica Editora, 1994.

NUNES, Ana Bela. Education and economic growth in Portugal: a simple regression approach. Estudos de Economia, 12 (2), p. 181-205, 1993.

PEREIRA, Miriam Halpern. Livre câmbio e desenvolvimento económico. Lisbon: Sá da Costa, 1983.

REIS, Eustáquio J. A economia brasileira no século XX. CAPES/CNPq/U. de Salamanca, 2-4 Sept. 02. Available at: <http://www.nemesis.org.br/erj002.pdf>.

REIS, Jaime. O atraso económico em perspectiva histórica, 1860-1913. In: $O$ atraso económico português. Lisbon: Casa da Moeda, 1993a, (first presentation, 1984), p. 9-32.

. O analfabetismo em Portugal no século XIX: uma interpretação. In:

O atraso económico português. Lisbon: Casa da Moeda, 1993b. p. 227-253. (first presentation, 1984).

. The historical roots of the modern Portuguese economy: the first century of growth, 1850s to 1950s. In: HERR, Richard (ed.). The New Portugal: democracy and Europe. Berkeley: University of California Press, 1993c, p. 126-148.

RODRÍGUEZ, Francisco; RODRIK, Dani. Trade policy and economic growth: a skeptic's guide to the cross-national evidence. In: BERNANKE, Ben; ROGOFF, Kenneth S. (eds.). Macroeconomics Anmual 2000. Cambridge, MA: MIT Press for NBER, 2001.

RODRIK, Dani. Political economy of trade policy. In: GROSSMAN, G.; ROGOFF, K. (eds.). Handbook of International Economics, v. 3, p. 1457-1494, 1995.

. The new global economy and developing countries: making openness work. Overseas Development Council, Washington, DC, 1999.

ROMER, Paul. Increasing returns and long run growth. Journal of Political Economy, 94, p. 1002-1037, 1986.

ROSAS, Fernando. A crise de 1929 e os seus efeitos económicos na sociedade portuguesa. O Estado Novo, das origens ao fim da autarcia 1926-1959, vol. I, Lisbon: Fragmentos, 1987.

RUBIO, María del Mar. Protectionist but globalised? Latin American custom duties and trade during the pre-1914 belle époque. Universidad Pompeu Fabra, Department of Economics and Business, 2006. Manuscript.

SERRÃO, Joel. A emigração portuguesa. Lisboa: Livros Horizonte,1974.

; MARTINS, Gabriela. Introdução. Da indústria portuguesa: do antigo regime ao capitalismo. Antologia. Lisboa: Livros Horizonte, 1978. 
SUZIGAN, Wilson. Indústria brasileira: origem e desenvolvimento. São Paulo: Brasiliense, 1986.

VALÉRIO, Nuno. Recent developments on Portuguese retrospective national accounts. Working Paper GHES, n 12 , ISEG, 1998.

. Estatísticas históricas portuguesas. Lisbon: INE, 2001.

VILLELA, André. Política tarifária no II reinado: evolução e impactos, 1850-1889. Nova Economia, 15, p. 35-68, jan-abr. 2005.

YANIKKAYA, Halit.Trade openness and economic growth: a cross-country empirical investigation. Journal of Development Economics, 72-1, p. 57-89, Oct. 2003. 


\section{APPENDIX 1}

TABLE I - PORTUGAL: PRE WORLD WAR I (1870 TO 1913)

Dependent Variable: GROWTH

Method: Least Squares

Date: 02/10/06 Time: 12:54

Sample(adjusted): 18731913

Included observations: 41 after adjusting endpoints

Convergence achieved after 10 iterations

Newey-West HAC Standard Errors \& Covariance (lag truncation=3)

\begin{tabular}{lllll}
\hline Variable & Coefficient & Std. Error & t-Statistic & Prob. \\
\hline C & -411.1478 & 97.79507 & -4.204177 & 0.0003 \\
TARIFF & 14.73764 & 2.980733 & 4.944302 & 0.0000 \\
PTNRTAR & 37.82497 & 7.735509 & 4.889784 & 0.0000 \\
TARIFF*PTNRTAR & -1.222758 & 0.236662 & -5.166692 & 0.0000 \\
EFFDIST & 0.151946 & 0.043969 & 3.455794 & 0.0020 \\
TARIFF*EFFIST & -0.005107 & 0.001385 & -3.686840 & 0.0011 \\
KIDSKOOLGR(-1) & -1.398864 & 0.507506 & -2.756353 & 0.0108 \\
RAILWAYSGR(-1) & -0.247653 & 0.135405 & -1.828979 & 0.0794 \\
EXPORTSGR(-1) & -0.001904 & 0.106368 & -0.017902 & 0.9859 \\
EXPORTS & -0.079903 & 0.005033 & -15.87664 & 0.0000 \\
D(LANDLABOR) & 222.1040 & 32.54802 & 6.823886 & 0.0000 \\
URBGR(-1) & 1.848252 & 0.845219 & 2.186713 & 0.0383 \\
AR(1) & -0.740632 & 0.190509 & -3.887644 & 0.0007 \\
AR(2) & -1.025598 & 0.158432 & -6.473437 & 0.0000 \\
AR(3) & -0.591261 & 0.203211 & -2.909583 & 0.0075 \\
AR(4) & -0.433745 & 0.162631 & -2.667046 & 0.0132 \\
\hline R-square & 0.762311 & Mean dependent var & 0.475704 \\
Adjusted R-square & 0.619697 & S.D. dependent var & 5.018112 \\
S.E. of regression & 3.094605 & Akaike info criterion & 5.382989 \\
Sum squared resid & 239.4146 & Schwarz criterion & 6.051700 \\
Log likelihood & -94.35128 & F-statistic & & 5.345285 \\
Durbin-Watson stat & 2.366629 & Prob(F-statistic) & 0.000121 \\
\hline Inverted AR Roots & $.15+.85 i$ & $.15-.85 i$ & $-.52+.57 i$ & $-.52-.57 i$ \\
\hline & & & \\
\hline
\end{tabular}


TABLE 2 - BR AZIL: PRE WORLD WAR I PERIOD (1870-1913)

Dependent Variable: GROWTH_CH_REV

Method: Least Squares

Date: 02/10/06 Time: 10:53

Sample(adjusted): 18741913

Included observations: 40 after adjusting endpoints

Convergence achieved after 16 iterations

Newey-West HAC Standard Errors \& Covariance (lag truncation=3)

\begin{tabular}{lllll}
\hline Variable & Coefficient & Std. Error & t-Statistic & Prob. \\
\hline C & -144.0525 & 55.09342 & -2.614696 & 0.0147 \\
TARIFF & 3.085643 & 1.487860 & 2.073879 & 0.0481 \\
PTNRTAR & 6.042378 & 2.187723 & 2.761948 & 0.0104 \\
TARIFF*PTNRTAR & -0.116704 & 0.062032 & -1.881338 & 0.0712 \\
EFFDIST & 0.006742 & 0.004553 & 1.480758 & 0.1507 \\
TARIFF*EFFDIST & -0.000207 & 0.000120 & -1.730591 & 0.0954 \\
KIDSKOOLGR(-1) & -0.076950 & 0.512488 & -0.150149 & 0.8818 \\
RAILWAYGR(-1) & -0.489500 & 0.079677 & -6.143522 & 0.0000 \\
EXPORTSGR(-1) & -0.033600 & 0.040151 & -0.836840 & 0.4103 \\
EXPORTS & 0.003042 & 0.001522 & 1.998786 & 0.0562 \\
D(LANDLABOR) & 0.258369 & 0.424217 & 0.609050 & 0.5478 \\
AR(1) & 0.434050 & 0.188119 & 2.307311 & 0.0293 \\
AR(2) & -0.152182 & 0.191239 & -0.795768 & 0.4334 \\
AR(3) & -0.458930 & 0.172376 & -2.662383 & 0.0131 \\
\hline R-square & 0.733971 & Mean dependent var & 0.930320 \\
Adjusted R-square & 0.600957 & S.D. dependent var & 7.754088 \\
S.E. of regression & 4.898248 & Akaike info criterion & 6.284849 \\
Sum squared resid & 623.8135 & Schwarz criterion & 6.875957 \\
Log likelihood & -111.6970 & F-statistic & 5.517982 \\
Durbin-Watson stat & 1.721520 & $-.71 i$ & 0.000109 \\
\hline Inverted AR Roots & $.52+.71 i$ & & \\
\hline & & & \\
\hline
\end{tabular}


TABLE 3 - PORTUGAL: INTERWAR YEARS (1919-1938)

Dependent Variable: GROWTH

Method: Least Squares

Date: 02/10/06 Time: 12:47

Sample: 19191938

Included observations: 20

Convergence achieved after 29 iterations

Newey-West HAC Standard Errors \& Covariance (lag truncation=2)

\begin{tabular}{lllcc}
\hline Variable & Coefficient & Std. Error & t-Statistic & Prob. \\
\hline C & -58.77241 & 6.235699 & -9.425152 & 0.0007 \\
TARIFF & 2.572809 & 0.530224 & 4.852309 & 0.0083 \\
PTNRTAR & 4.831242 & 0.675840 & 7.148496 & 0.0020 \\
TARIFF*PTNRTAR & -0.183266 & 0.029740 & -6.162367 & 0.0035 \\
EFFDIST & 0.006318 & 0.001196 & 5.283467 & 0.0062 \\
TARIFF*EFFDIST & -0.000724 & 0.000253 & -2.858406 & 0.0460 \\
KIDSKOOLGR(-1) & 0.291438 & 0.314838 & 0.925675 & 0.4070 \\
RAILWAYSGR(-1) & 0.361498 & 0.079151 & 4.567205 & 0.0103 \\
EXPORTSGR(-1) & -0.054181 & 0.056651 & -0.956404 & 0.3930 \\
EXPORTS & 0.005783 & 0.003522 & 1.642229 & 0.1759 \\
D(LANDLABOR) & -104.8918 & 160.7227 & -0.652626 & 0.5496 \\
URBGR(-1) & 5.091244 & 2.701509 & 1.884592 & 0.1326 \\
AR(1) & -1.307265 & 0.187553 & -6.970092 & 0.0022 \\
AR(2) & -1.932465 & 0.306541 & -6.304102 & 0.0032 \\
AR(3) & -1.085927 & 0.277759 & -3.909597 & 0.0174 \\
AR(4) & -0.639383 & 0.172203 & -3.712967 & 0.0206 \\
\hline R-square & 0.993706 & Mean dependent var & 4.012774 \\
Adjusted R-square & 0.970102 & S.D. dependent var & 10.47741 \\
S.E. of regression & 1.811662 & Akaike info criterion & 4.016929 \\
Sum squared resid & 13.12848 & Schwarz criterion & 4.813515 \\
Log likelihood & -24.16929 & F-statistic & & 42.09920 \\
Durbin-Watson stat & 3.221034 & $-.17+.91 i$ & $-.48-.71 i$ & 0.001229 \\
\hline Inverted AR Roots & $-.17+.91 i$ & & $-.48+.71 i$ \\
\hline & & & \\
\hline
\end{tabular}


TABLE 4 - BR AZIL: INTERWAR YEARS (1919 -1938)

Dependent Variable: GROWTH_CH_REV

Method: Least Squares

Date: 02/10/06 Time: 10:51

Sample: 19191938

Included observations: 20

Convergence achieved after 25 iterations

Newey-West HAC Standard Errors \& Covariance (lag truncation=2)

\begin{tabular}{|c|c|c|c|c|}
\hline Variable & Coefficient & Std. Error & t-Statistic & Prob. \\
\hline C & 705.3431 & 51.14605 & 13.79076 & 0.0000 \\
\hline TARIFF & -14.06902 & 2.267978 & -6.203331 & 0.0008 \\
\hline PTNRTAR & -17.88354 & 1.961868 & -9.115566 & 0.0001 \\
\hline TARIFF*PTNRTAR & 0.528025 & 0.089552 & 5.896323 & 0.0011 \\
\hline EFFDIST & -0.044360 & 0.005250 & -8.448947 & 0.0002 \\
\hline TARIFF*EFFDIST & 0.002050 & 0.000273 & 7.518072 & 0.0003 \\
\hline KIDSKOOLGR(-1) & -0.446859 & 0.130699 & -3.418985 & 0.0142 \\
\hline RAILWAYGR(-1) & 15.03752 & 2.605313 & 5.771864 & 0.0012 \\
\hline EXPORTSGR(-1) & 0.353743 & 0.040680 & 8.695743 & 0.0001 \\
\hline EXPORTS & -0.028524 & 0.003213 & -8.876979 & 0.0001 \\
\hline D(LANDLABOR) & 131.6299 & 12.87388 & 10.22457 & 0.0001 \\
\hline $\operatorname{AR}(1)$ & -1.025748 & 0.173970 & -5.896113 & 0.0011 \\
\hline $\mathrm{AR}(2)$ & -0.871892 & 0.297773 & -2.928040 & 0.0264 \\
\hline $\mathrm{AR}(3)$ & -0.120452 & 0.105328 & -1.143588 & 0.2964 \\
\hline R-square & 0.961339 & \multicolumn{2}{|c|}{ Mean dependent var } & 2.675487 \\
\hline Adjusted R-square & 0.877573 & \multicolumn{2}{|c|}{ S.D. dependent var } & 8.748866 \\
\hline S.E. of regression & 3.061190 & \multicolumn{2}{|c|}{ Akaike info criterion } & 5.271512 \\
\hline Sum squared resid & 56.22530 & \multicolumn{2}{|c|}{ Schwarz criterion } & 5.968524 \\
\hline Log likelihood & -38.71512 & \multicolumn{2}{|c|}{ F-statistic } & 11.47651 \\
\hline Durbin-Watson stat & 2.727919 & \multicolumn{2}{|c|}{ Prob(F-statistic) } & 0.003397 \\
\hline Inverted AR Roots & -.17 & $-.43+.74 \mathrm{i}$ & $-.43-$ & \\
\hline
\end{tabular}


TABLE 5 - TEST FOR JOINT SIGNIFICANCE OF EXPLANATORY VARIABLES FOR PORTUGAL: PRE-WORLD WAR I YEARS

Redundant Variables: TARIFF PTNRTAR TARIFF*PTNRTAR EFFDIST

TARIFF*EFFDIST KIDSKOOLGR(-1) RAILWAYSGR(-1)

EXPORTSGR(-1) EXPORTS D(LANDLABOR) URBGR(-1)

\begin{tabular}{llll}
\hline F-statistic & 6.754055 & Probability & 0.000039 \\
Log likelihood ratio & 56.54783 & Probability & 0.000000 \\
\hline
\end{tabular}

Test Equation:

Dependent Variable: GROWTH

Method: Least Squares

Sample: 18731913

Included observations: 41

Convergence achieved after 2 iterations

Newey-West HAC Standard Errors \& Covariance (lag truncation=3)

\begin{tabular}{|c|c|c|c|c|}
\hline Variable & Coefficient & Std. Error & t-Statistic & Prob. \\
\hline C & 0.474612 & 0.727224 & 0.652636 & 0.5181 \\
\hline $\mathrm{AR}(1)$ & 0.107319 & 0.188225 & 0.570161 & 0.5721 \\
\hline $\operatorname{AR}(2)$ & -0.212188 & 0.146309 & -1.450273 & 0.1556 \\
\hline $\mathrm{AR}(3)$ & 0.088694 & 0.154654 & 0.573503 & 0.5699 \\
\hline$A R(4)$ & 0.046009 & 0.120017 & 0.383355 & 0.7037 \\
\hline R-square & 0.055949 & \multicolumn{2}{|c|}{ Mean dependent var } & 0.475704 \\
\hline Adjusted R-square & -0.048946 & \multicolumn{2}{|c|}{ S.D. dependent var } & 5.018112 \\
\hline S.E. of regression & 5.139452 & \multicolumn{2}{|c|}{ Akaike info criterion } & 6.225619 \\
\hline Sum squared resid & 950.9030 & \multicolumn{2}{|c|}{ Schwarz criterion } & 6.434592 \\
\hline Log likelihood & -122.6252 & \multicolumn{2}{|c|}{ F-statistic } & 0.533382 \\
\hline Durbin-Watson stat & 1.911690 & \multicolumn{2}{|c|}{ Prob(F-statistic) } & 0.712006 \\
\hline Inverted AR Roots & .48 & $-.05+.60 \mathrm{i}$ & $-.05-.60 \mathrm{i}$ & -.27 \\
\hline
\end{tabular}


TABLE 6 - TEST FOR JOINT SIGNIFICANCE OF EXPLANATORY VARIABLES FOR BRAZIL: PRE-WORLD WAR I YEARS

Redundant Variables: TARIFF PTNRTAR TARIFF*PTNRTAR EFFDIST

TARIFF*EFFDIST KIDSKOOLGR(-1) RAILWAYGR(-1) EXPGR(-1)

EXPORTS D(LANDLABOR)

\begin{tabular}{lllc}
\hline F-statistic & 2.246096 & Probability & $0.047567^{68}$ \\
Log likelihood ratio & 24.90648 & Probability & 0.005526 \\
\hline
\end{tabular}

Test Equation:

Dependent Variable: GROWTH_CH_REV

Method: Least Squares

Sample: 18741913

Included observations: 40

Convergence achieved after 3 iterations

Newey-West HAC Standard Errors \& Covariance (lag truncation $=3$ )

\begin{tabular}{lllll}
\hline Variable & Coefficient & Std. Error & t-Statistic & Prob. \\
\hline C & 0.338674 & 1.809199 & 0.187195 & 0.8526 \\
AR(1) & 0.767012 & 0.160642 & 4.774655 & 0.0000 \\
AR(2) & -0.025884 & 0.156149 & -0.165766 & 0.8693 \\
AR(3) & -0.292889 & 0.139279 & -2.102902 & 0.0425 \\
\hline R-square & 0.504153 & Mean dependent var & 0.930320 \\
Adjusted R-square & 0.462833 & S.D. dependent var & 7.754088 \\
S.E. of regression & 5.683103 & Akaike info criterion & 6.407511 \\
Sum squared resid & 1162.716 & Schwarz criterion & 6.576399 \\
Log likelihood & -124.1502 & F-statistic & 12.20103 \\
Durbin-Watson stat & 1.552024 & Prob(F-statistic) & 0.000012 \\
\hline Inverted AR Roots & $.62+.48 i$ & $.62-.48 i$ & -.48 \\
\hline
\end{tabular}

68 This statistic shows that after accounting for lagged correlation, other coefficients on the explanatory variable were significantly different from zero. 
TABLE 7 - TEST FOR JOINT SIGNIFICANCE OF EXPLANATORY VARIABLES FOR PORTUGAL: INTERWAR YEARS

Redundant Variables: TARIFF PTNRTAR TARIFF*PTNRTAR EFFDIST

TARIFF*EFFDIST KIDSKOOLGR(-1) RAILWAYSGR(-1)

EXPORTSGR(-1) EXPORTS D(LANDLABOR) URBGR(-1)

\begin{tabular}{llll}
\hline F-statistic & 30.38049 & Probability & 0.002413 \\
Log likelihood ratio & 88.74600 & Probability & 0.000000 \\
\hline
\end{tabular}

Test Equation:

Dependent Variable: GROWTH

Method: Least Squares

Sample: 19191938

Included observations: 20

Convergence achieved after 3 iterations

Newey-West HAC Standard Errors \& Covariance (lag truncation=2)

\begin{tabular}{lllll}
\hline Variable & Coefficient & Std. Error & t-Statistic & Prob. \\
\hline C & 4.361689 & 1.876425 & 2.324467 & 0.0345 \\
AR(1) & -0.002245 & 0.143564 & -0.015640 & 0.9877 \\
AR(2) & -0.133483 & 0.176019 & -0.758347 & 0.4600 \\
AR(3) & 0.472508 & 0.195776 & 2.413511 & 0.0290 \\
AR(4) & -0.216553 & 0.306363 & -0.706851 & 0.4905 \\
\hline R-square & 0.467834 & Mean dependent var & 4.012774 \\
Adjusted R-square & 0.325922 & S.D. dependent var & 10.47741 \\
S.E. of regression & 8.602191 & Akaike info criterion & 7.354229 \\
Sum squared resid & 1109.965 & Schwarz criterion & 7.603162 \\
Log likelihood & -68.54229 & F-statistic & 3.296667 \\
Durbin-Watson stat & 1.949481 & Prob(F-statistic) & & 0.039757 \\
\hline Inverted AR Roots & $.48-.22 i$ & $.48+.22 i$ & $-.48-.74 i$ & $-.48+.74 \mathrm{i}$ \\
\hline
\end{tabular}


TABLE 8 - TEST FOR JOINT SIGNIFICANCE OF EXPLANATORY VARIABLES FOR BRAZIL: INTERWAR YEARS

Redundant Variables: TARIFF PTNRTAR TARIFF*PTNRTAR

EFFDIST TARIFF*EFFDIST KIDSKOOLGR(-1) RAILWAYGR(-1) EXPGR(-1) EXPORTS D(LANDLABOR)

\begin{tabular}{lllr}
\hline F-statistic & 8.353755 & Probability & $0.00857^{69}$ \\
Log likelihood ratio & 54.05797 & Probability & 0.000000 \\
\hline
\end{tabular}

Test Equation:

Dependent Variable: GROWTH_CH_REV

Method: Least Squares

Sample: 19191938

Included observations: 20

Convergence achieved after 3 iterations

Newey-West HAC Standard Errors \& Covariance (lag truncation=2)

\begin{tabular}{lllll}
\hline Variable & Coefficient & Std. Error & t-Statistic & Prob. \\
\hline C & 2.769991 & 1.898681 & 1.458902 & 0.1639 \\
AR(1) & 0.500605 & 0.157301 & 3.182465 & 0.0058 \\
AR(2) & -0.059735 & 0.201374 & -0.296639 & 0.7706 \\
AR(3) & -0.394322 & 0.211508 & -1.864338 & 0.0807 \\
\hline R-square & 0.423063 & Mean dependent var & 2.675487 \\
Adjusted R-square & 0.314887 & S.D. dependent var & 8.748866 \\
S.E. of regression & 7.241572 & Akaike info criterion & 6.974410 \\
Sum squared resid & 839.0459 & Schwarz criterion & 7.173557 \\
Log likelihood & -65.74410 & F-statistic & 3.910883 \\
Durbin-Watson stat & 1.527942 & Prob(F-statistic) & & 0.028557 \\
\hline Inverted AR Roots & $.54-.63 i$ & $.54+.63 i$ & -.58 & \\
\hline
\end{tabular}

69 This statistic shows that after accounting for lagged correlation, other coefficients on explanatory variable were significantly different from zero. 


\section{APPENDIX 2 - DATA}

Comparison of $\mathrm{CH}$ data (annual growth in per capita Revenue, Cr\$ at 1949 prices) with CW data (annual growth in GDP per capita, 1990 US \$)

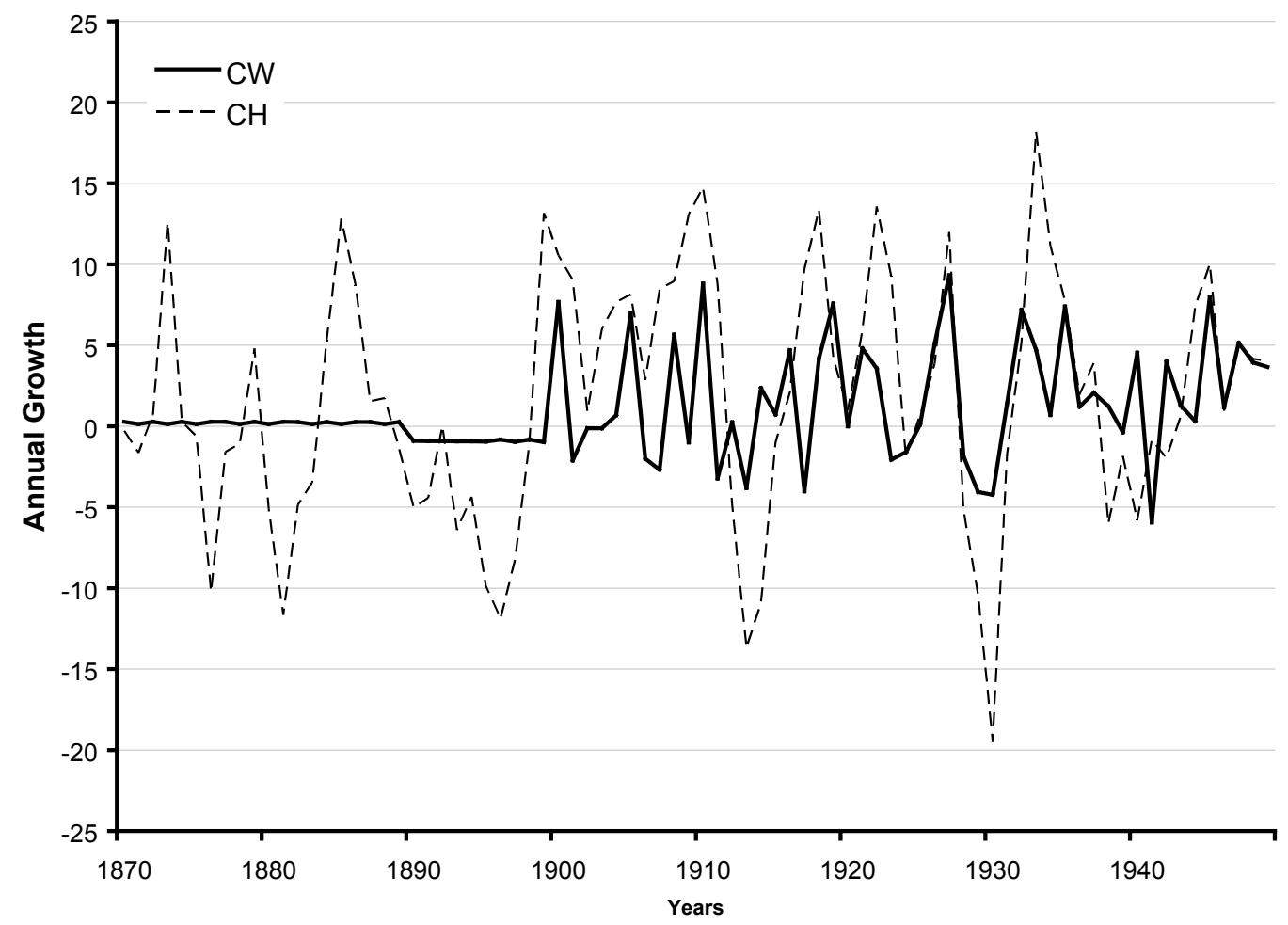

For Brazil, a series of regressions with alternative dependent variables were performed separately for the period before and after the World War I. From the graph it is clear that $\mathrm{CH}$ data exhibits more variability, especially before 1900. Indeed, pre-1900 data points simply seem to be a backward projection of the average rate of growth after that year. Therefore we used the $\mathrm{CH}$ data in preference to those of $\mathrm{CW}$, derived from Goldsmith. The dependent variable used was annual growth in GDP capita. 